\title{
Development of immune-complex glomerulonephritis in athymic mice: $T$ cells are not required for the genesis of glomerular injury
}

\author{
Nayer Bagheri ${ }^{1}$, Douglas A Pepple ${ }^{1}$, Medhat O Hassan ${ }^{2}$, Clifford V Harding ${ }^{1}$ and \\ Steven N Emancipator ${ }^{1}$ \\ ${ }^{1}$ Department of Pathology, Case Western Reserve University, Cleveland, OH, USA and ${ }^{2}$ Louis Stokes \\ Cleveland Veterans' Affairs Medical Center, Cleveland, OH, USA
}

\begin{abstract}
Chronic injection of dextran into normal mice elicits a glomerulonephritis (GN) that models IgA nephropathy (IgAN) in humans. Since athymic mice lack $T$ cells but nonetheless develop antibodies to polysaccharide antigens such as dextran (DEX), we used athymic mice to study the role of T lymphocytes in the induction of this form of GN, independent of the role of T cells in antibody synthesis. Both mice given injections of diethylaminoethyl (DEAE)-DEX and uninjected mice had circulating IgM and IgA anti-DEX antibodies, which apparently arise as 'natural antibodies,' but immune complex GN was observed only in the injected mice. All of 15 injected mice exhibited capillary staining for IgA and IgM; none of 12 control mice contained such IgA deposits and only one had capillary staining for IgM (both $P<0.001$ ). In addition, IgG and C3 were detected in injected but not control animals. By light microscopy, injected mice exhibited marked expansion of mesangial matrix relative to controls. Electron microscopy showed no glomerular abnormalities in control mice, whereas injected mice showed large organized fibrillar deposits principally in the mesangium. Hematuria and proteinuria were present in all 15 injected mice, but only one of 11 control mice showed hematuria or proteinuria (both $P<0.001)$. These results indicate that chronic injection of DEAE-DEX into athymic mice generates the same clinical and histologic features of GN as in euthymic mice, suggesting that T cells are not necessary to promote GN in this model.
\end{abstract}

Laboratory Investigation (2005) 85, 354-363, advance online publication, 31 January 2005; doi:10.1038/labinvest.3700243

Keywords: glomerulonephritis; IgA nephropathy; athymic mice; thymus-independent antigen

T cells may participate in glomerular injury, either directly or in concert with immune complexes. ${ }^{1-10}$ $\mathrm{T}$ cells clearly modulate antibody responses to T-dependent antigens, and the resulting antibodies can contribute to immune complex-mediated glomerulonephritis (GN). ${ }^{1,2}$ Moreover, Tipping et $a l^{8}$ reported that macrophage accumulation in experimental anti-glomerular basement membrane antibodyinduced GN is preceded by T-cell accumulation. Therefore, $\mathrm{T}$ cells may shape the physiologic responses to immune complexes deposited within target organs.

Correspondence: Dr SN Emancipator, MD, Institute of Pathology, Case Western Reserve University, 2085 Adelbert Rd, Cleveland, OH 44106, USA.

E-mail: sne@cwru.edu

Received 31 July 2003; revised 19 November 2004; accepted 21 November 2004; published online 31 January 2005
The role of $\mathrm{T}$ lymphocytes in promoting GN has also been examined in nude mice, which lack a thymus and therefore an effective T-cell system. Earlier studies, using immune complex and autoimmune models of glomerulonephritis, suggested that $\mathrm{T}$ cells were necessary for the development of nephritis. ${ }^{3,6}$ A more recent study of experimental crescentic GN also showed that athymic mice fail to develop glomerular lesions. ${ }^{9}$ Adoptive transfer of T lymphocytes into athymic mice restores disease susceptibility, and therefore suggests a critical role for $\mathrm{T}$ lymphocytes in the pathogenesis of crescentic GN. ${ }^{5}$ Collectively, these studies indicate that cellular immunity plays an important role in the development of glomerulonephritis, but they do not demonstrate a requirement for $\mathrm{T}$ cells beyond participation in the genesis of suitable humoral responses.

Several studies have suggested that T cells do play a direct role in promoting glomerular injury. After deposition of rabbit gammaglobulin in rat glomeruli, 
adoptive transfer of antigen-specific syngeneic $\mathrm{T}$ cells can elicit GN. ${ }^{2}$ Bolton et al, ${ }^{4}$ using neonatally bursectomized chickens, also directly demonstrated a role for cell-mediated immunity in the development of nephritis. Most recently, Radeke et $a l^{10}$ demonstrated that appropriate phenotypes of clonotypic $\mathrm{T}$ cells can elicit proteinuria in immunodeficient mice, if specific antigen accumulates within the glomerular mesangium prior to the adoptive transfer of the effector/memory cells. Although these experiments indicate that $\mathrm{T}$ cells have the capacity to provoke glomerular injury directly without the participation of antibody, they do not establish a requirement for $\mathrm{T}$ cells in humorally mediated glomerulonephritis beyond the necessity for T cells in antibody generation.

Active injection of dextran (DEX) into euthymic mice produces a glomerulonephritis that clinically and pathologically resembles IgA nephropathy (IgAN), a spontaneously occurring human disease. ${ }^{11,12}$ DEX, with a polymeric structure of repeating oligosaccharide epitopes, is one of those antigens considered to be T-independent, ${ }^{13}$ and DEX-specific antibodies arise in athymic mice. ${ }^{14}$ Antibody responses to T-independent antigens consist primarily of IgM with low affinity; affinity maturation, due to somatic hypermutation, and class-switching to other isotypes are not well developed in the immune responses to such antigens, although some IgG and/or IgA anti-DEX antibodies can arise in athymic mice.

Herein, we report the use of athymic mice to explore the role of $\mathrm{T}$ cells in the genesis of glomerulonephritis actively induced by DEX immunization. Since T-cell function is not required for synthesis of anti-DEX antibody, anti-DEX antibodies arise in both athymic and euthymic mice, and circulating immune complexes can be generated in both types of animal. Yet, athymic mice are severely deficient in functional $\mathrm{T}$ cells, especially conventional $(\alpha / \beta \mathrm{TCR})$ antigen-specific $\mathrm{T}$ cells. Thus, a requirement for $\mathrm{T}$ cells in the genesis of humorally mediated glomerular injury, beyond that for B-cell help, can be assessed using athymic subjects. After injection of diethylaminoethyl (DEAE)-DEX, athymic mice developed glomerular deposits of IgA, IgM, IgG and C3, accompanied by hematuria and proteinuria, similar to the disease that develops in euthymic mice. ${ }^{11,12}$ Uninjected mice failed to develop these features. These observations suggest that $\mathrm{T}$ cells are not necessary for the initiation of glomerular injury in this form of GN.

\section{Materials and methods}

\section{Induction of GN}

Both male and female athymic mice (BALB/c, nu/ nu), 6-8 weeks old, were obtained from the Cancer Center of Case Western Reserve University (Cleveland, $\mathrm{OH}, \mathrm{USA})$. Mice were randomly assigned to either of two groups. The experimental group received intraperitoneal (i.p.) injections of $1 \mathrm{mg}$ of $500 \mathrm{kDa}$ DEAE-DEX (Sigma, St Louis, MO, USA) in $0.3 \mathrm{ml} \mathrm{PBS}, \mathrm{pH} 7.4$, on days 1,7 and 10 , followed by intravenous (i.v.) injections of $1 \mathrm{mg}$ of the same DEAE-DEX solution thrice weekly from day 14 until day 75 , for a total of $30 \mathrm{mg}$ DEAE-DEX. ${ }^{11,12}$ The control group received no injections.

\section{Clinical Assessment of GN}

After the last i.v. injection, experimental and control mice were placed into individual metabolic cages, and urine was collected overnight. The volume of the timed urine collection was recorded and corrected to $24 \mathrm{~h}$. Urine was tested with Hemastix ${ }^{\mathbb{B}}$ (Bayer Corp., Diagnostics Division, Elkhart, IN, USA) and Albustix ${ }^{\circledR}$ (Miles Inc., Diagnostics Division, Elkhart, IN, USA). The hematuria score for each mouse was graded (0-4) from the dipstick reflectance as specified by the manufacturer. After centrifugation ( $800 \mathrm{~g}$ for $10 \mathrm{~min}$ at $4{ }^{\circ} \mathrm{C}$ ), urine supernatants were assayed for quantitative protein excretion by the sulfosalicylic acid method. ${ }^{11}$ Protein excretion, expressed as mg/day, was calculated from the 24-h volume and the concentration. Urine sediments were examined microscopically for the presence of erythrocytes. ${ }^{11}$ All mice scored positive by dipstick ( $>$ trace) showed at least 25 red cells per high power field, but all scored negative by dipstick had fewer than five red cells per high power field. Mice were subsequently exsanguinated under ether anesthesia, and serum derived from clotted blood was used for serologic measurements. Both kidneys were removed for morphologic studies.

\section{Tissue Preparation and Morphometric Analyses}

Samples of kidney from each animal were fixed in $10 \%$ buffered formalin and embedded in paraffin, or fixed in $2.5 \%$ glutaraldehyde and embedded in Epon ${ }^{\circledR}$, for light and electron microscopy, respectively. ${ }^{11}$ Another portion of each kidney was snapfrozen in isopentane immersed into liquid nitrogen, and sectioned in a cryostat at $4 \mu \mathrm{m}$. Paraffin sections $(2 \mu \mathrm{m})$ were stained with periodic acid-Schiff. Cryostat sections were stained with fluoresceinated IgG fractions of goat antisera specific for mouse IgM, IgA, IgG, or C3 (Organon Teknika Corp., Durham, NC, USA); antibody specificity was controlled as previously detailed. ${ }^{11}$ To quantify glomerular immune deposits, the intensity of staining for each reactant was scored from 0 (no staining) to 4 (intense global staining) in at least 15 glomeruli per mouse. The arithmetic mean value for each mouse was then analyzed.

For morphometric analysis of extracellular matrix accumulation, digital images of at least 25 glomeruli per mouse were taken at $\times 40$ objective via an Olympus BH-2 microscope (Olympus Corp., Tokyo) 
with a Spot Insight Color camera system (model 3.2.0) using provided software (Diagnostic Instruments, Inc., Sterling Heights, MI, USA). The photos were then adjusted using Adobe Photoshop CS 8.0 (Adobe Systems, Inc., San Jose, CA, USA) to create a grayscale image from magenta (PAS meta-chromatic staining) to white, after adding green luminosity to remove background cyan counterstain. The images were measured by NIH Image 1.63 software (NIH, Rockville, MD, USA) using a common predetermined thresholding level. The total area occupied by above-threshold pixels was converted to square microns after calibration using digital images of a stage micrometer (Bausch \& Lomb, Rochester, NY, USA).

\section{Murine Myeloma Proteins}

Purified MOPC 104E (IgM anti- $\alpha$-glucosyl [1-3] glucoside) and MOPC 315 (IgA anti-dinitrophenol) myeloma proteins were purchased from Organon Teknika Corp. Cells of the myeloma J558, which secrete IgA anti- $\alpha$-glucosyl [1-3] glucoside, were purchased from the American Type Culture Collection (ATCC, Rockville, MD, USA) and cultured as suggested by the ATCC. For expansion of myeloma in ascites, euthymic BALB/c mice (Charles River, Wilmington, MA, USA) received $0.5 \mathrm{ml}$ of pristane intraperitoneally; 1 week later, $2 \times 10^{6}$ cultured J558 cells were injected intraperitoneally into each mouse. Ascites, which developed 2-3 weeks after inoculation of cells, was collected from these mice. The IgA was precipitated by $40 \%$ saturated ammonium sulfate, redissolved in PBS, extracted in Seroclear Reagent (Calbiochem, La Jolla, CA, USA), and dialyzed against PBS. Monoclonal IgG antibody R4A $\gamma 2 B$ from ascites from SCID mice, a kind gift from $\mathrm{Dr} B$ Diamond (Albert Einstein College of Medicine, Bronx, NY, USA), was purified (after Seroclear extraction) by ammonium sulfate precipitation and elution from protein G-Sepharose.

\section{Serum Antibody Analysis}

Anti-DEX antibody levels (IgM, IgA and IgG) were measured by an ELISA technique, as previously published..$^{12}$ DEX was conjugated to bovine serum albumin (BSA) by adding $1 \mathrm{ml}$ of a $2 \mathrm{mg} / \mathrm{ml}$ DEX solution in borate buffer $(0.2 \mathrm{M}, \mathrm{pH} 9.0)$ to $0.5 \mathrm{ml}$ of 0.1 M BSA (United States Biochemical Corp., Cleveland, OH, USA). Next, $10 \mu \mathrm{l}$ of a $0.1 \mathrm{M}$ solution of sodium periodate was added, with stirring. After $1 \mathrm{~min}, 50 \mu \mathrm{l}$ of $2.0 \mathrm{M}$ sodium borohydride was added, and the preparation was dialyzed against sodium bicarbonate $(0.2 \mathrm{M}, \mathrm{pH}$ 9.6). The resulting DEX-BSA was used to coat 96-well microtiter ELISA plates (Thomas Scientific, Swedesboro, NJ, USA) for $4 \mathrm{~h}$ at room temperature. The plates were washed three times with PBS ( $\mathrm{pH} 7.4)$, and subsequently blocked by incubation with $1 \%$ BSA in sodium carbonate-bicarbonate buffer ( $\mathrm{pH}$ 9.6) overnight at $4^{\circ} \mathrm{C}$. Next, the plates were washed three times with PBS (pH 7.4), and standards or test sera from experimental or control mice were added at optimal dilution (in PBS) and incubated for $4 \mathrm{~h}$ at room temperature. After sample incubation, the plates were washed three times with PBS (pH 7.4), and alkaline phosphatase-conjugated goat anti-mouse antibodies (each specific for one of the heavy chains of IgM, IgA, or IgG, Southern Biotechnology Associates, Inc., Birmingham, AL, USA) were incubated overnight at $4^{\circ} \mathrm{C}$. The plates were washed three times more, and substrate (disodium $p$-nitrophenyl phosphate, $1 \mathrm{mg} / \mathrm{ml}$, in $0.1 \mathrm{M}$ glycine, $1 \mathrm{mM} \mathrm{MgCl}_{2}$, $1 \mathrm{mM} \mathrm{ZnCl}_{2}$, pH 10.4) was added for $0.5-1 \mathrm{~h}$ at room temperature. Hydrolysis of substrate in the wells was followed at $414 \mathrm{~nm}$ in a microplate photometer (Cayman Chemical, Ann Arbor, MI, USA). The optical density developed with anti-mouse IgM was interpolated into a standard curve with MOPC 104E monoclonal IgM, and that developed with antiIgA was interpolated into a standard curve established with J558 monoclonal IgA. Values for levels of IgM and IgA antibody in samples are expressed as $\mathrm{mg} / \mathrm{ml}$ MOPC 104E equivalents or $\mu \mathrm{g} / \mathrm{ml} \mathrm{J558}$ equivalents, respectively. Because no monoclonal IgG anti-DEX antibody was available as a standard, data for IgG antibody were presented as arbitrary (O.D.) units.

The specificity of these assays was tested in three ways. First, for antigen displacement, free DEX was added to sample wells at varying concentrations $(0.125-8 \mathrm{mg} / \mathrm{ml})$ with a fixed dilution of serum samples or purified standards. Second, exogenous purified anti-DEX antibodies (J558 IgA or MOPC $104 \mathrm{E}$ IgM) were added at different dilutions to a fixed dilution of standards or sample serum from each mouse. Finally, the binding of serum anti-DEX antibodies or purified anti-DEX myeloma proteins to unconjugated BSA was compared to binding of parallel samples incubated in wells coated with DEX-BSA conjugate. In all cases, detection of bound Ig of each isotype was performed as above.

Anti-double-stranded DNA (dsDNA) antibody titers were measured by ELISA as previously described. ${ }^{15,16}$ Briefly, Immunolon 2 plates (Fisher Scientific, Pittsburgh, PA, USA) were coated (uncovered) by incubation of $10 \mu \mathrm{g} /$ well of salmon sperm dsDNA (Calbiochem-Novabiochem, La Jolla, CA, USA) at $37^{\circ} \mathrm{C}$ overnight, and blocked by incubation with $1 \%$ BSA in PBS for $2 \mathrm{~h}$ at room temperature. Mouse sera (serially diluted up to 1:4000) or purified R4A $\gamma 2 \mathrm{~B}$ anti-dsDNA IgG standards $(1.56-200 \mu \mathrm{g} / \mathrm{ml})$ were applied for $2 \mathrm{~h}$ at room temperature. After three washes with PBS, alkalinephosphatase goat anti-mouse IgG antibody (heavy and light chain specific, Southern Biotechnology Associates) was incubated for $1 \mathrm{~h}$ at room temperature. The plates were developed using $p$-nitrophenyl phosphate (Sigma) as above, and the absorbance at $405 \mathrm{~nm}$ was determined in an automated microplate 
reader (Bio-Tek Instruments, Inc., Winooski, VT, USA). The optical density was interpolated into a standard curve calculated using the R4A $\gamma 2 \mathrm{~B}$ standard, and results are expressed as $\mu \mathrm{g} / \mathrm{ml}$ equivalents of R4A $\gamma 2 \mathrm{~B}$. Inhibition ELISA was performed as above, except that serum was incubated in the presence of either $100 \mu \mathrm{g} / \mathrm{ml}$ soluble dsDNA, $100 \mu \mathrm{g} / \mathrm{ml}$ free DEAE-DEX, or $1 \mathrm{mg} / \mathrm{ml}$ BSA.

For determination of total IgG concentration, microplates were coated with goat anti-mouse IgG, and samples (diluted up to 1:100 000 in $0.1 \%$ BSAPBS) were applied for $2 \mathrm{~h}$ at room temperature. Subsequent steps of washing, detection and development were performed as noted above. Again, purified $\mathrm{R} 4 \mathrm{~A} \gamma 2 \mathrm{~B}$ was used as a standard.

\section{Statistical Analysis}

All continuous (quantitative) variables were analyzed by two-way analysis of variance, stratified for experiment and for treatment group (injected or not). No significant differences were observed between the two replicate experiments, and these results were pooled. Post hoc analysis was performed with Scheffe's $F$-statistic (quoted with $P$-values).

Discontinuous (qualitative count) variables (ie 'positive' vs 'negative') were analyzed by the $\chi^{2}$ test, and $\chi^{2}$-values are quoted with the associated $P$-values.

\section{Results}

\section{Dextran-Specific IgM, IgA, IgG Antibodies Arise in Athymic Mice}

In two independent experiments, specific anti-DEX IgM, IgA and IgG antibodies were detected in the sera of both the injected and control groups of athymic mice (Table 1). IgM was the major class of antibody produced. Thus, DEX-specific antibodies can occur as natural antibodies ${ }^{17-20}$ without prior deliberate immunization. In fact, noninjected animals had significantly higher levels of serum IgM anti-DEX $(2.72 \pm 0.42 \mathrm{mg} / \mathrm{ml})$ than injected mice $(1.71 \pm 0.14 \mathrm{mg} / \mathrm{ml}, \quad P<0.02, \quad F=6.2)$; noninjected mice also had significantly higher levels of serum IgA anti-DEX $(38.0 \pm 2.7 \mu \mathrm{g} / \mathrm{ml})$ and $\operatorname{IgG}$ anti-DEX $(0.54 \pm 0.05 \mathrm{U})$ than injected animals

Table 1 Serum antidextran titers in nude mice

\begin{tabular}{lccc}
\hline Groups & $\begin{array}{c}\text { IgM anti-DEX } \\
(\mathrm{mg} / \mathrm{ml})\end{array}$ & $\begin{array}{c}\text { IgA anti-DEX } \\
(\mu \mathrm{g} / \mathrm{ml})\end{array}$ & $\begin{array}{c}\text { IgG anti-DEX } \\
\text { (OD units })\end{array}$ \\
\hline Control $(n=12)$ & $2.72 \pm 0.42$ & $38.0 \pm 2.7$ & $0.54 \pm 0.05$ \\
Injected $(n=15)$ & $1.71 \pm 0.14^{*}$ & $32.0 \pm 0.5^{*}$ & $0.33 \pm 0.03^{*}$
\end{tabular}

Data are mean \pm s.e.

${ }^{*}$ Significantly lower than control mice $(P<0.02, F>5.9)$.
$(32.0 \pm 0.5 \mu \mathrm{g} / \mathrm{ml}$ and $0.33 \pm 0.03 \mathrm{U}$, respectively, both $P<0.02, F \geq 5.99$ ).

The specificity of the anti-DEX antibody was confirmed by antigen displacement experiments, wherein addition of free DEX to serum samples or standards in ELISA displaced the binding of antiDEX IgM (Figure 1) and IgG antibodies (data not shown), as a monotonic function of free DEX concentration. Moreover, addition of varying amounts of the murine monoclonal IgA anti- $\alpha$ glucosyl [1-3] glucoside (J558) also monotonically displaced binding of IgM and IgG anti-DEX by ELISA, whereas addition of irrelevant IgA (MOPC 315) had no effect (Figure 2). Similar displacement of IgA antibodies in samples or J558 standards was observed when MOPC 104E (IgM anti- $\alpha$-glucosyl [1-3] glucoside) was admixed with the samples (data not shown). The specificity of this ELISA system was further supported by the observation that the specific (above-background) binding of myeloma or serum antibodies to BSA-DEX was lost in the wells coated with BSA alone, for every sample tested, whether IgM (Figure 3), IgA (not shown) or IgG (not shown) antibody was measured. We conclude that natural DEX-specific antibodies occur in athymic mice, with or without administration of DEX.

Immunoglobulin binding to ds DNA was detected in the sera of three of 15 injected mice $(20 \%)$ and seven of 12 noninjected mice $(58 \%)$. However, the level of anti-DNA exceeded $500 \mathrm{ng} / \mathrm{ml}$ in only one injected $(7 \%$, moderate titer) and four noninjected mice $(33 \%)$. Furthermore, among these five mice with low $(\sim 2 \mu \mathrm{g} / \mathrm{ml}$, two noninjected mice), moderate $(2.5-8 \mu \mathrm{g} / \mathrm{ml}$, two mice) or high ( $>8 \mu \mathrm{g} / \mathrm{ml}$, one noninjected mouse) anti-dsDNA titers, one with

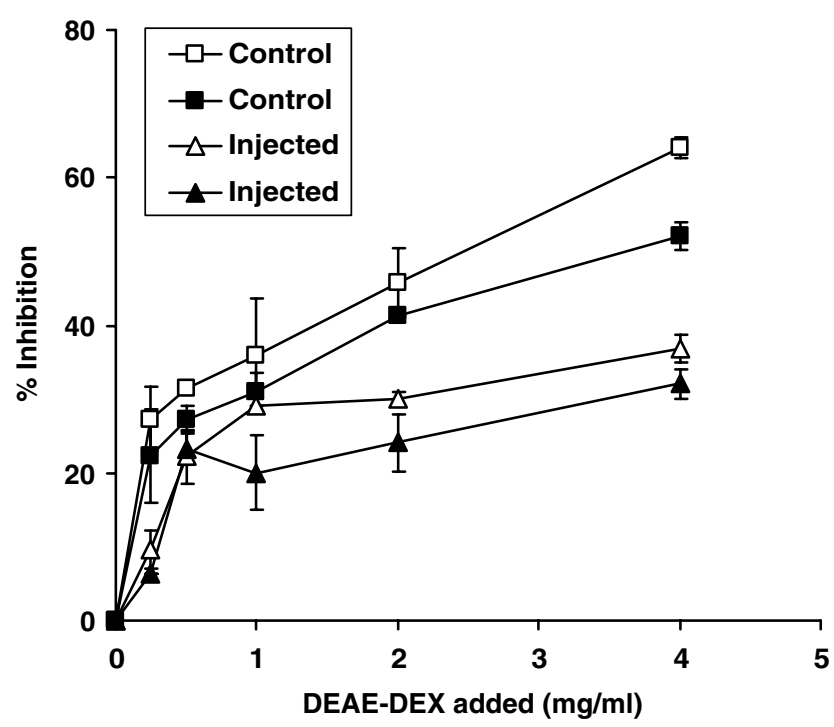

Figure 1 Inhibition of serum IgM (anti-DEX) binding to DEX-BSA coated plates by DEX in solution. Free DEX, added at increasing concentrations, monotonically displaced the binding of antibody in sera from two representative control $(\square, \mathbf{Q})$ and two representative injected $(\triangle, \boldsymbol{\Delta})$ mice. 
moderate titer and one with low titer (both noninjected) did not exhibit reduced binding in the presence of exogenous soluble dsDNA, suggesting that the bound Ig was not specific for dsDNA. Although total serum IgG in noninjected mice was somewhat higher than in injected mice $(4.2 \pm 0.3$ compared to $2.8 \pm 0.3 \mathrm{mg} / \mathrm{ml}$, respectively, $P<0.01$, $F=6.8$ ), these mean values represent only $19-28 \%$ of the level of IgG detected in euthymic controls. Finally, those murine sera reactive with dsDNA, with the exception of the single noninjected mouse with a high titer $(10 \mu \mathrm{g} / \mathrm{ml})$ greatly inhibited by exogenous dsDNA, all had higher than average total serum IgG titers; in fact, those with $>500 \mathrm{ng} / \mathrm{ml}$ anti-DNA levels and no detectable antigen inhibition were all at the upper confidence limit for total

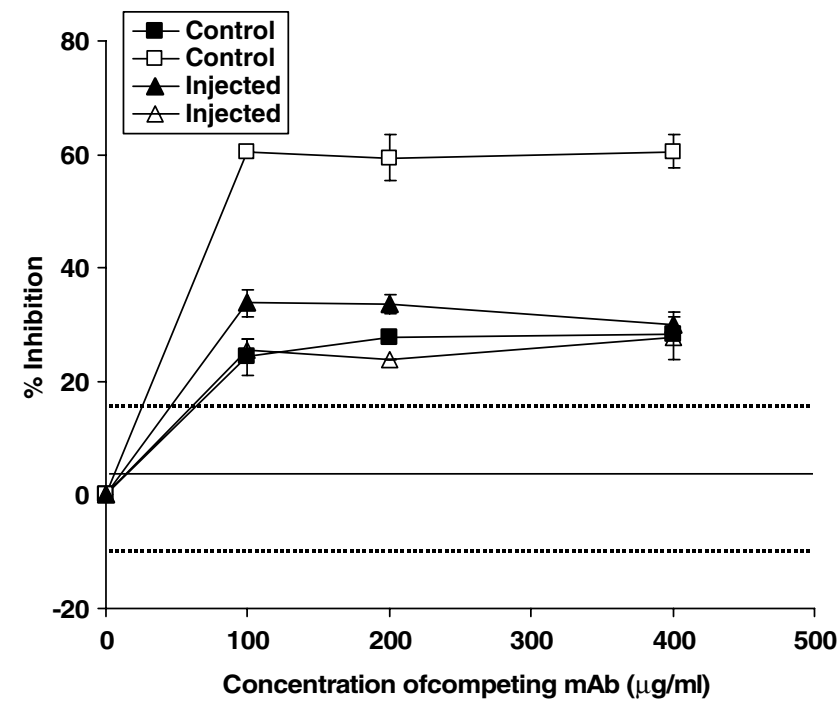

Figure 2 Competition of serum anti-DEX IgM by J558 (IgA). Various dilutions of J558 purified from ascites were added to serum samples from representative control $(\square, \mathbf{\square})$ or injected mice $(\triangle, \boldsymbol{\Delta})$ in duplicate wells. Antibody bound to the plates was detected by alkaline phosphatase-conjugated goat anti-mouse IgM (not cross-reactive with murine IgA). Addition of MOPC 315 at the same concentration had no effect on binding of IgM to the plate; the mean percent inhibition by MOPC 315 is the solid horizontal rule; upper and lower confidence intervals ( \pm 2 s.d.) are shown as dotted lines. Similar inhibition of IgA antibody in sera was observed using IgM anti-DEX Ab (MOPC 104E) followed by detection with anti-murine IgA (not cross-reactive with IgM).
IgG. In sum, only one injected (7\%) and two noninjected $(17 \%)$ mice had appreciable antigenspecific anti-DNA titers.

\section{Morphologic Changes in Glomeruli}

Although anti-DEX antibodies occurred even in naive mice, administration of DEX was necessary to generate glomerular deposits of immune complexes (Table 2) and consequent GN. By immunofluorescence microscopy (Figure 4), all of the 15 injected mice in two independent experiments showed moderate to intense capillary wall deposits of IgA and IgM (Table 2); none of the 12 control mice had such deposits of IgA $\left(P<0.001, \chi^{2}=27\right)$, and only one had capillary deposits of IgM $(P<0.001$, $\chi^{2}=23.2$ ). Background mesangial deposits of IgA and IgM were detected in all mice, injected or not, but mice injected with DEX exhibited a significantly (both $P<0.001, F \geq 35.4$ ) higher intensity of IgA (mean fluorescence intensity $1.97 \pm 0.18$ ) and of IgM

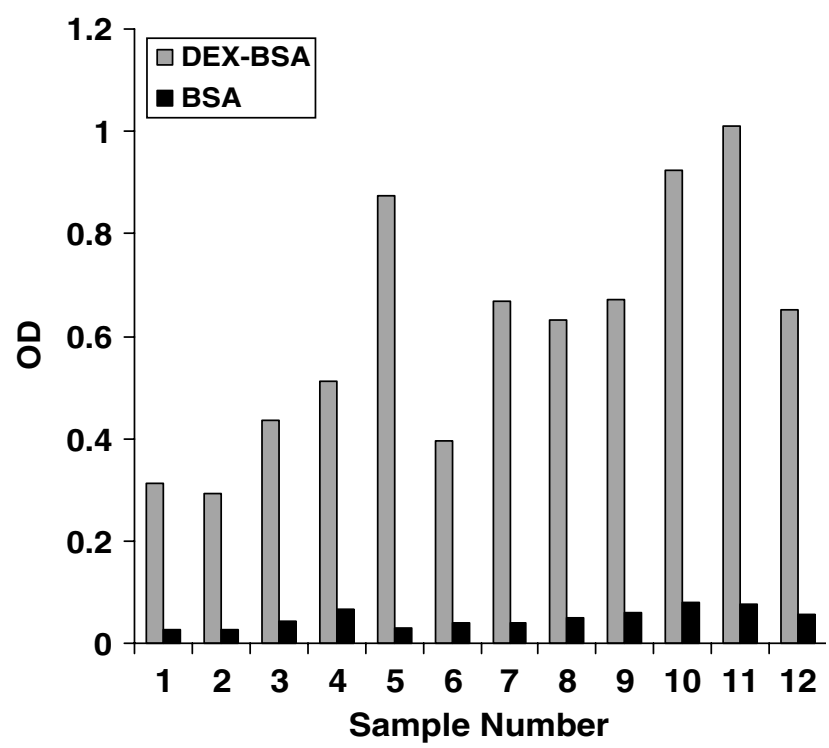

Figure 3 Dextran-specific binding of sera from athymic mice. All sera showed high binding to DEX-BSA (shaded bars) compared to the consistently lower binding to BSA (black bars). Samples (numbered 1-12 here) represent 9 injected (1-9) mice and 3 controls (10-12).

Table 2 Deposits of antibody and complement in normal controls and mice immunized with DEAE-DEX detected by immunofluorescence

\begin{tabular}{lcrrr}
\hline Groups & $\operatorname{Ig} A$ & $\operatorname{Ig} M$ & $\operatorname{IgG}$ & \multicolumn{1}{c}{$C 3$} \\
\hline Control $(n=12)$ & $0(0.69 \pm 0.08)$ & $8(1.54 \pm 0.17)$ & $8(0.55 \pm 0.05)$ & $17(0.31 \pm 0.09)$ \\
Injected $(n=15)$ & $100^{*}(1.97 \pm 0.18)^{\dagger}$ & $100^{*}(3.01 \pm 0.18)^{\dagger}$ & $47^{*}(0.77 \pm 0.12)$ & $53^{*}(0.67 \pm 0.12)^{\dagger}$
\end{tabular}

Data are the percent mice scored positive (and mean fluorescence intensity \pm s.e.). For IgA, IgG or C3, any score above equivocal/trace is considered as positive; IgM positivity is based entirely on capillary deposits (see text). In mice injected with dextran, Ig and C3 deposits were localized principally in the capillaries.

${ }^{*}$ Significantly more frequent than in control mice $\left(\chi^{2}=27\right.$ for IgA, 23.2 for IgM, 4.7 for IgG and 3.9 for C3).

${ }^{\dagger}$ Significantly higher intensity score compared to control ( $F>35$ for IgM, IgA; 5.3 for C3). 

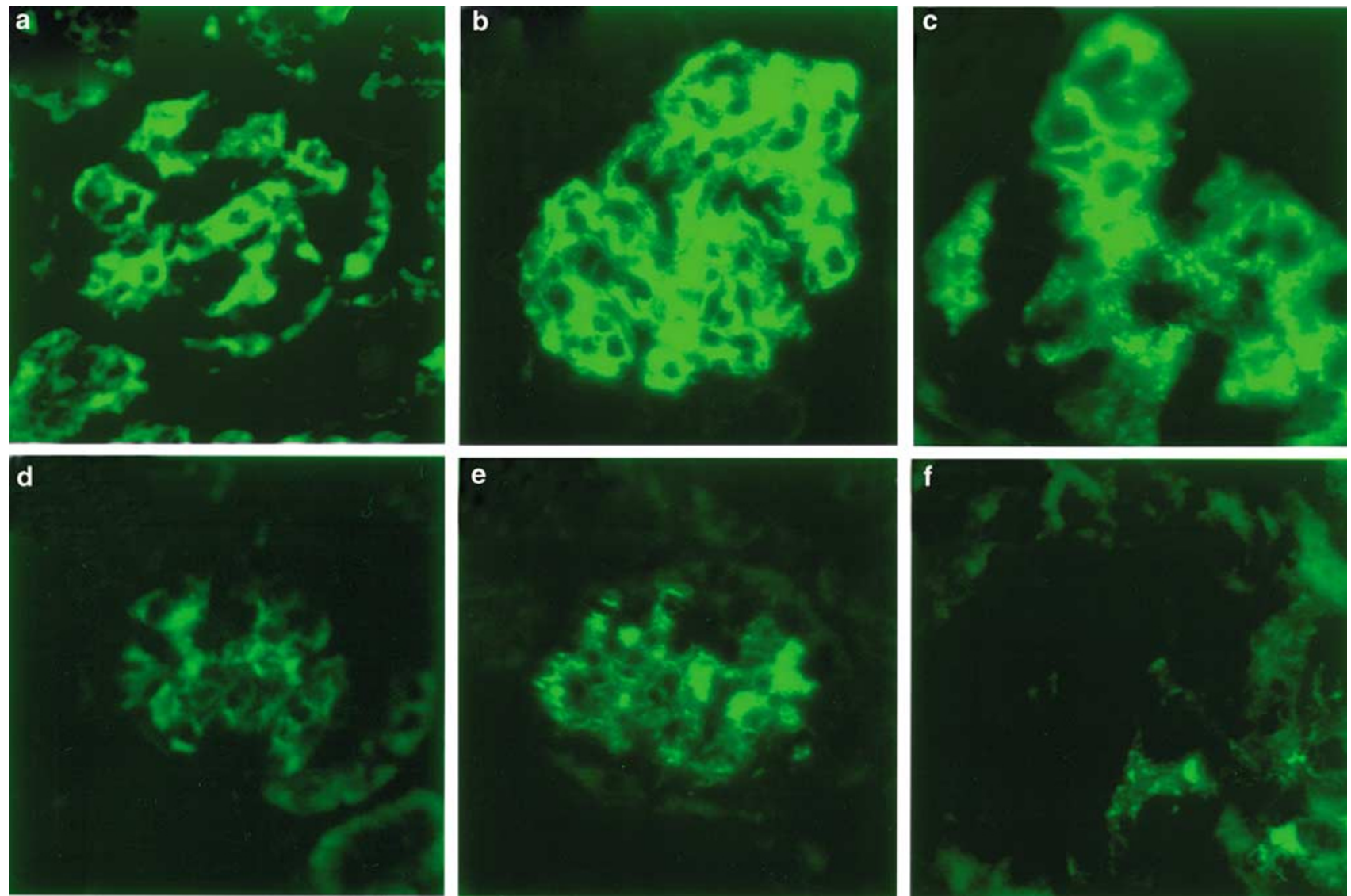

Figure 4 Representative immunofluorescence micrographs. All injected mice (a), showed moderately bright capillary and mesangial IgA deposits, distinct from the weak background mesangial staining in one-third of the control mice (d). Intense capillary and mesangial IgM deposits in injected mice (b) differ from the background mesangial IgM staining in control mice (e). At higher magnification, the mixed capillary wall and mesangial distribution of granular IgA deposits in glomeruli from injected mice (c) contrasts with the background fluorescence confined to mesangial areas in control mice (f).

$(3.01 \pm 0.18)$ compared to noninjected controls $(0.69 \pm 0.08$ and $1.54 \pm 0.17$ respectively, Table 2$)$. Codeposits of IgG and C3 (Table 2) were present in $47 \%$ and $53 \%$ of injected mice, significantly higher than the corresponding frequencies $(8 \%$ for IgG and $17 \%$ for C3) observed in noninjected controls (both $P<0.05, \chi^{2} \geq 3.85$ ). The mean fluorescence intensity for C3 deposits in injected mice $(0.67 \pm 0.12)$ was significantly $(P<0.05, F=5.3)$ higher than that in controls $(0.31 \pm 0.09)$, but the mean intensity of $\operatorname{IgG}$ deposits did not differ between injected $(0.77 \pm 0.12)$ and control $(0.55 \pm 0.05)$ mice.

By light microscopy, expanded mesangial matrix and segmentally variable thickening of glomerular capillary basement membranes, in association with mild increases in mesangial cellularity but no endocapillary proliferation or leukocytic infiltrate, were observed in all 15 injected mice (Figure 5a), but these changes were uniformly absent from any of the 12 noninjected mice (Figure 5b). Morphometric analysis revealed that extracellular matrix in glomeruli from injected mice occupied $2813 \pm 62 \mu \mathrm{m}^{2}$, compared to only $633 \pm 39 \mu \mathrm{m}^{2}$ in noninjected controls $(P<0.001, F>100)$. No tubulointerstitial abnormality was detected in any mouse.
Glomerular ultrastructure was examined by electron microscopy of kidneys from five control mice and five given injections of DEAE-DEX. All five mice given DEAE-DEX exhibited large fibrillar deposits with organized substructure in the mesangium (Figure 6a), which were not seen in any control mice (Figure 6b). Conversely, the amorphous granular deposits previously reported to be localized in the subepithelial space in normal athymic mice ${ }^{21}$ were detected in the control mice (Figure 6d), but were only observed in two of the five injected mice examined (Figure 6c). In addition, injected mice showed segmentally variable fusion of epithelial foot processes (Figure 6c), not seen in noninjected control animals (Figure 6d). In summary, welldeveloped immune deposits and mesangial proliferative GN were present in mice injected with DEX, but not in control mice.

\section{Development of Hematuria and Proteinuria in Athymic Mice}

GN was evidenced by pathologic changes in glomerular function as well as by the presence of 

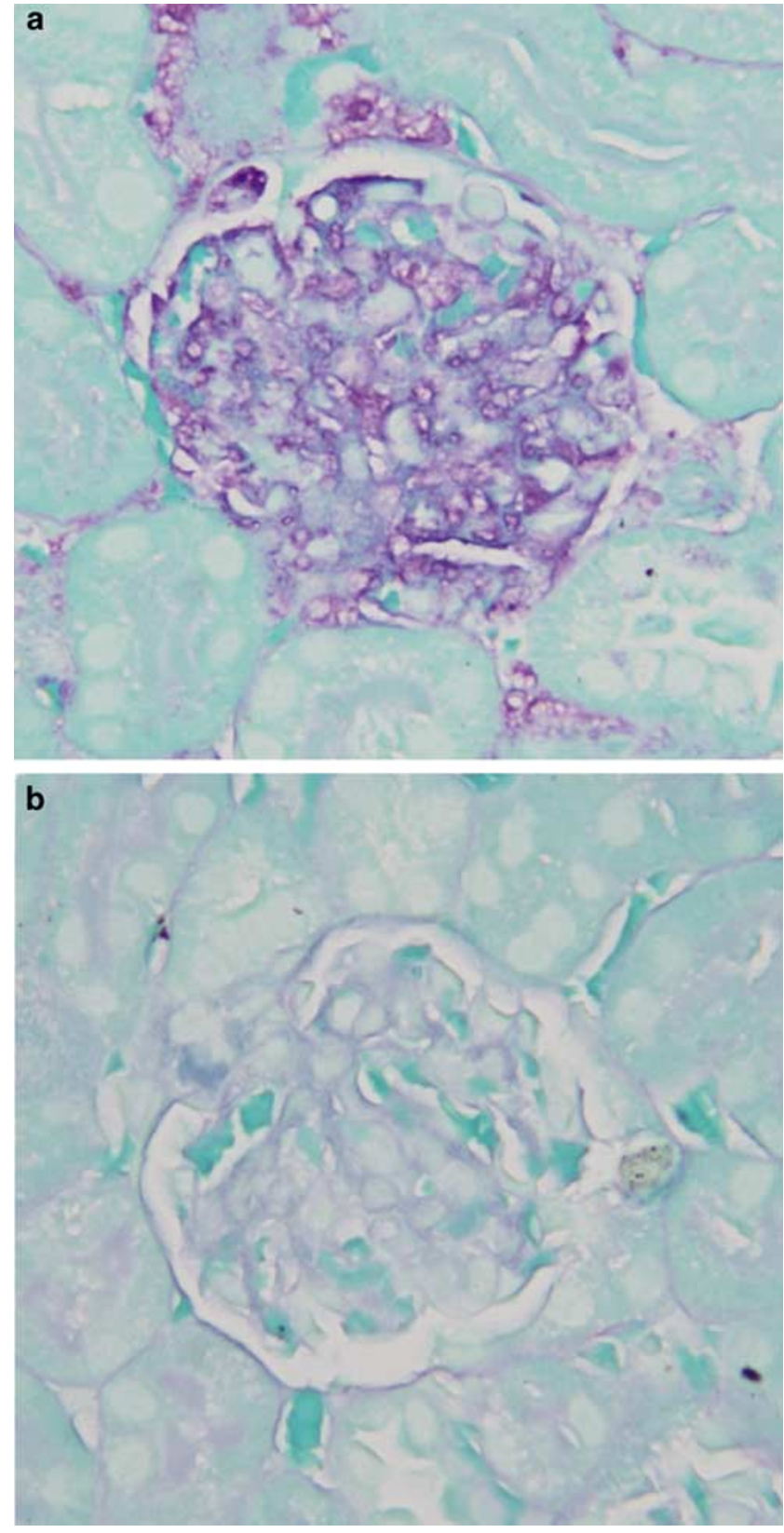

Figure 5 Representative light micrographs. In injected mice (a), mesangial matrix is moderately to severely expanded, with segmentally variable mild mesangial hypercellularity and encroachment upon or narrowing of glomerular capillary area. In addition, glomerular capillary basement membranes are thickened. In contrast, glomeruli in noninjected control mice (b) reveal fully patent capillaries delimited by normally thick and delicate basement membranes; the mesangial matrix is not expanded, and mesangial cellularity appears normal.

immune complexes. All 15 mice that received DEAE-DEX injections developed hematuria and proteinuria as detected by dipstick (Table 3). Hematuria was confirmed by light microscopic examination of the urinary sediment (25-42 erythrocytes per high power field). One of 11 noninjected controls had hematuria and proteinuria detectable by dipstick, but neither abnormality was present in the other 10 mice $\left(P<0.001, \chi^{2}=22.2\right.$ compared to injected mice). Urine was not recovered from one control animal. The mean hematuria score $(1.87 \pm 0.20)$ and mean urinary protein excretion $(1.64 \mathrm{mg} /$ day \pm 0.21$)$ in injected mice both significantly $(P<0.01, F>8.5)$ exceeded the corresponding values in noninjected controls $(0.25 \pm 0.09$ and $0.66 \pm 0.01$, respectively). We conclude that injection of dextran promotes GN with proteinuria and hematuria in athymic mice.

\section{Discussion}

Unlike other immunodeficient mice, such as SCID and RAG- knockout mice that have a general absence of mature functional $\mathrm{T}$ and $\mathrm{B}$ cells, athymic mice have functional $B$ cells which can produce antibodies to T-independent antigens. ${ }^{14,22}$ Anti-DEX antibodies were present in sera from both naive and DEAE-DEX-injected athymic mice. As expected, the major antibody isotype produced by athymic mice was IgM; IgA and IgG were detected at considerably lower levels. Surprisingly, the levels of anti-DEX antibodies of all isotypes were significantly higher in control mice than in injected mice. The specificity of the assay was confirmed by three different methods; all three methods support this finding. We propose that when injected frequently into athymic mice, DEAE-DEX combines with circulating natural anti-DEX antibodies of all isotypes, ${ }^{17-20}$ resulting in the elimination of the antibody from the circulation by deposition of immune complexes into the tissues and/or clearance by mononuclear phagocytes. Consistent with this scheme, immune-complex GN developed in athymic mice after injection of DEAE-DEX. The development of DEX-induced GN in this athymic mouse model implies that the initiation of glomerular injury can be completely independent of T-cell function in situations where adequate antibody responses arise without T-cell help.

The mechanisms that mediate tissue injury and clinical symptoms in this model in athymic mice are unknown. One possible factor is mesangial complement deposition. We have previously demonstrated that hematuria in passively induced IgAN is caused by codeposition of complement along with complement-fixing immunoglobulin isotypes (IgM, IgG) in the kidney. ${ }^{23}$ Indeed, among the murine models of IgAN, those with hematuria and glomerular dysfunction are typically the ones with mesangial complement deposition; ${ }^{23-26}$ conversely, those without complement generally have normal glomerular function. ${ }^{27-29}$ However, in the system described herein, a pathogenic role for the complement system is improbable, since hematuria occurred even in mice with little or no glomerular C3 deposits.

Alternately, the interaction of mesangial cells with immune complexes may be a critical element in 

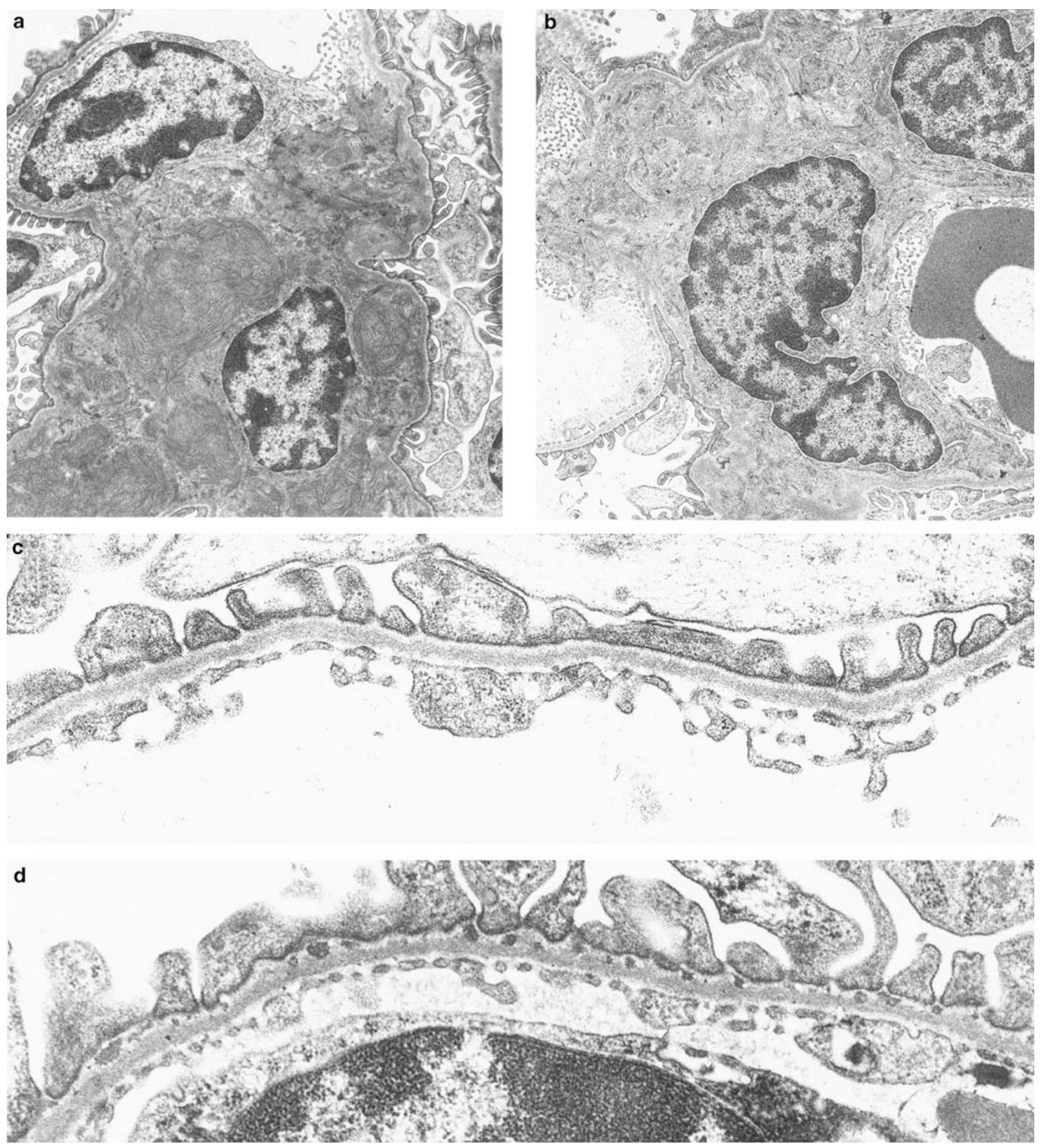

Figure 6 Ultrastructural examination of glomeruli by electron microscopy. Glomeruli from nude mice injected with DEAE-DEX show large fibrillar deposits in the mesangium (a), not present in controls (b). Injected mice (c) showed segmental broadening and flattening of epithelial podocytes, but most were devoid of deposits in glomerular capillary walls. The amorphous granular subepithelial deposits normally present in athymic mice were seen in all five control mice examined (d), but there was no podocyte fusion.

the pathogenesis of IgAN. Previously, we $^{30}$ and others $^{31,32}$ have reported the expression of a receptor for the $F_{C}$ region of $\operatorname{IgA}\left(F_{C} \alpha\right)$ on mesangial cells. Aggregated IgA elicits from mesangial cells the release of inflammatory mediators, including superoxide anion, IL-6 and TNF- $\alpha^{32-35}$ Moreover, IgA and cytokines such as IL-6, TNF- $\alpha$ and to a lesser extent IFN- $\gamma$ can increase the capacity for mesangial cells to bind IgA, establishing the potential for a positive feedback amplification of glomerular injury. ${ }^{30,33}$ In addition, residual natural killer cells circulating in athymic mice may produce 
Table 3 Effect of injected dextran on kidney function

\begin{tabular}{lcccc}
\hline Groups & $\begin{array}{c}\text { Hematuria } \\
\text { (Hemastix) }^{\mathrm{a}}\end{array}$ & $\begin{array}{c}\text { Hematuria } \\
(\text { mean score) }\end{array}$ & $\begin{array}{c}\text { Proteinuria } \\
\text { (Albustix) }^{\mathrm{a}}\end{array}$ & $\begin{array}{c}\text { Proteinuria } \\
(\text { mg/day) }\end{array}$ \\
\hline $\begin{array}{l}\text { Control } \\
(n=11)^{\mathrm{d}}\end{array}$ & 9 & $0.25 \pm 0.09$ & 9 & $0.66 \pm 0.01$ \\
$\begin{array}{l}\text { Injected } \\
(n=15)\end{array}$ & $100^{*}$ & $1.87 \pm 0.20^{\dagger}$ & $100^{*}$ & $1.64 \pm 0.21^{\dagger}$ \\
\hline
\end{tabular}

${ }^{\mathrm{a}}$ Data are percent mice positive by dipstick test.

${ }^{b}$ Data are the mean \pm s.e. semiquantitative hematuria value of the group.

${ }^{\mathrm{C}}$ Data are the mean \pm s.e. protein excretion of the group, based on sulfosalicylic acid precipitation.

${ }^{\mathrm{d}}$ One of the control mice had no urine.

*Significantly more frequent than in control mice (both $\gamma^{2}=22.2$ ).

${ }^{\dagger}$ Significantly higher than in control mice $(F>8.5)$.

IFN- $\gamma$ in response to immune complexes containing IgA, further contributing to onset and/or progression of disease. However, the release of these inflammatory factors has not been assessed in athymic mice. Accordingly, the specific mechanism(s) of glomerular injury in this model remain(s) obscure.

In our system, the cationic antigen (DEAE-DEX) is continuously present in the circulation and has affinity for glomerular polyanions. ${ }^{12,25,36-39} \mathrm{IgM}$, the major Ig isotype in the serum of athymic mice, probably generates large circulating IgM immune complexes that localize poorly in the glomeruli. Although the serum IgA anti-DEX antibody level is much less than that of IgM, IgA was detected at high density in glomerular deposits. Thus, it is likely that IgA deposits in glomeruli by the mechanism of in situ complex formation. This might explain why the IgA deposits are as prominent or even more prominent than IgM deposits, even though the IgM antibody level in the circulation is at least 50 times higher. Although cationized human IgM $(900 \mathrm{kDa})$ penetrates the glomerular filtration barrier poorly, cationized macromolecules as large as ferritin $(480 \mathrm{kDa})$ easily penetrate the GBM. ${ }^{39}$ Accordingly, circulating IgA molecules (150$450 \mathrm{kDa}$ ) would have better access to cationic DEX planted within the GBM than the larger IgM molecules. Over time, cationic DEX and/or DEX/ IgM complexes accumulate initially in glomeruli by binding to anionic sites, and subsequently DEX planted in the glomeruli acts as a target for circulating specific antibodies, principally IgA, that have access to this region.

Overall, the data presented herein support the view that glomerular immune complexes can mediate the morphologic signs and clinical symptoms of IgA nephropathy independent of at least conventional $(\alpha / \beta$ TCR) antigen-specific T cells. These data also suggest that in situ formation of immune complexes within glomeruli causes this pattern of glomerulonephritis.

\section{Acknowledgements}

We are grateful to Dr Michael E Lamm for his critical review of the manuscript and to Nancy Nagy and John France for their technical support. We also thank Jose Mariappuram from the CWRU Cancer Research Center for providing nude mice for this study. This work was supported by National Institutes of Health Grants AI 36359, AI 34343, AI 35726, CA 70149 and DK 59334.

\section{References}

1 Bhan AK, Collins AB, Schneeberger EE, et al. A cellmediated reaction against glomerular-bound immune complexes. J Exp Med 1979;150:1410-1420.

2 Bhan AK, Schneeberger EE, Collins AB, et al. Evidence for a pathogenic role of a cell-mediated immune mechanism in experimental glomerulonephritis. J Exp Med 1978;148:246-260.

3 Bolton WK, Benton FR, Lobo PI. Requirement of functional T-cells in the production of autoimmune glomerulotubular nephropathy in mice. Clin Exp Immunol 1978;33:474-477.

4 Bolton WK, Tucker FL, Sturgill BC. New avian model of experimental glomerulonephritis consistent with mediation by cellular immunity. Nonhumorally mediated glomerulonephritis in chickens. J Clin Invest 1984;73:1263-1276.

$5 \mathrm{Du}$ A, Zou W. The effect of T cells in pathogenesis of glomerular nephritis. Chung-Hua ping Li Hsueh Tsa Chih-Chin J Pathol 1993;22:347-349.

6 Hagstrom G, Bloom P, Yum M, et al. Immune complex nephritis in nude mice. Nephron 1981;29:95-98.

7 McCluskey RT. Immunologic aspects of renal disease. In: Heptinstall RH (ed). Pathology of the Kidney, 4th edn. Little, Brown \& Company: Boston, MA, 1992, pp 169-260.

8 Tipping PG, Neale TJ, Holdsworth SR. T lymphocyte participation in antibody-induced experimental glomerulonephritis. Kidney Int 1985;27:530-537.

9 Zhou K, Zou W. The roles of T cells in experimental crescentic glomerulonephritis. Chung-Hua ping Li Hsueh Tsa Chih-Chin J Pathol 1992;21:100-102.

10 Radeke HH, Tschernig T, Karulin A, et al. CD4+ T cells recognizing specific antigen deposited in glomeruli cause glomerulonephritis-like kidney injury. Clin Immunol 2002;104:161-173.

11 Gesualdo L, Ricanati S, Hassan MO, et al. Enzymolysis of glomerular immune deposits in vivo with dextranase/protease ameliorates proteinuria, hematuria, and mesangial proliferation in murine experimental IgA nephropathy. J Clin Invest 1990;86:715-722.

12 Isaacs KL, Miller F. Role of antigen size and charge in immune complex glomerulonephritis. I. Active induction of disease with dextran and its derivatives. Lab Invest 1982;47:198-205.

13 Sela M, Mozes E, Shearer GM. Thymus-independence of slowly metabolized immunogens. Proc Natl Acad Sci USA 1972;69:2696-2700.

14 Abbas AK, Lichtman AH, Pober JS. Cellular and Molecular Immunology, 3rd edn. WB Saunders Company: Philadelphia, PA, 1997.

15 Kuo P, Bynoe MS, Wang C, et al. Bcl-2 leads to expression of anti-DNA B cells but no nephritis: a 
model for a clinical subset. Eur J Immunol 1999;29: 3168-3178.

16 Sharma A, Isenberg D, Diamond B. Studies of human polyclonal and monoclonal antibodies binding to lupus autoantigens and cross-reactive antigens. Rheumatology 2003;42:453-463.

17 Berczi L, Bertok L, Chow DA. Natural immunity and neuroimmune host defense. Ann NY Acad Sci 2000;917:248-257.

18 Fagarasan S, Honjo T. T-independent immune response: new aspects of B cell biology. Science 2000; 290:89-92.

19 Martin F, Kearney JF. B-cell subsets and the mature preimmune repertoire. Marginal zone and B1 B cells as part of a 'natural immune memory'. Immunol Rev 2000;175:70-79.

20 Ochsenbein AF, Zinkernagel RM. Natural antibodies and complement link innate and acquired immunity. Immunol Today 2000;21:624-630.

21 Grishman E, Porush JC, Rosen SM, et al. Lupus nephritis with organized deposits in the kidneys. Lab Invest 1967;16:717-725.

22 Koskimies S, Makela O. T-cell-deficient mice produce more antihapten antibodies against syngeneic than against allogeneic erythrocyte conjugates. J Exp Med 1976;144:467-475.

23 Emancipator SN, Ovary Z, Lamm ME. The role of mesangial complement in the hematuria of experimental IgA nephropathy. Lab Invest 1987;57: 269-276.

24 Isaacs K, Miller F, Lane B. Experimental model for IgA nephropathy. Clin Immunol Immunopathol 1981;20: 419-426.

25 Isaacs KL, Miller F. Antigen size and charge in immune complex glomerulonephritis. II. Passive induction of immune deposits with dextran-antidextran immune complexes. Am J Pathol 1983;111:298-306.

26 Rifai A, Small PA, Teague PO, et al. Experimental IgA nephropathy. J Exp Med 1979;150:1161-1173.

27 Emancipator SN, Gallo GR, Lamm ME. Experimental IgA nephropathy induced by oral immunization. J Exp Med 1983;157:572-582.
28 Emancipator SN, Gallo GR, Razaboni R, et al. Experimental cholestasis promotes the deposition glomerular IgA immune complexes. Am J Pathol 1983;113:19-26.

29 Imai H, Nakamoto Y, Askaura K, et al. Spontaneous glomerular IgA deposition in ddY mice: an animal model of IgA nephritis. Kidney Int 1985;27:756-761.

30 Bagheri N, Chintalacharuvu S, Emancipator S. Proinflammatory cytokines regulate $\mathrm{Fc} \alpha \mathrm{R}$ expression by human mesangial cells in vitro. Clin Exp Immunol 1997;107:404-409.

31 Gomez-Guerrero C, Gonzalez E, Egido J. Evidence for a specific IgA receptor in rat and human mesangial cells. J Immunol 1993;151:7172-7181.

32 van den Dobbelsteen MEA, van der Woude FJ, Schroeijers WEM, et al. Binding of dimeric and polymeric IgA to renal mesangial cells enhances the release of IL-6. Kidney Int 1994;46:512-519.

33 Bagheri N, Emancipator SN. IgA stimulates expression of Fc $\alpha$ R mRNA and IL-6 production by human mesangial cells. The FASEB J 1996;10:A1433.

34 Emancipator SN. Primary and secondary forms of IgA nephritis, Schonlein-Henoch syndrome. In: Heptinstall RH (ed). Pathology of the Kidney. Little Brown: Boston, MA, 1992, pp 389-476.

35 Gomez-Guerrero C, Lopez-Armada MJ, Gonzalez E, et al. Soluble IgA and IgG aggregates are catabolized by cultured rat MC and induce production of TNF- $\alpha$ and IL-6, and proliferation. J Immunol 1994;153:5247-5255.

36 Batsford S, Oite T, Takamiya $\mathrm{H}$, et al. Anionic binding sites in the glomerular basement membrane: possible role in the pathogenesis of immune complex nephritis. Renal Physiol 1980;3:336-340.

37 Batsford SR, Takamiya H, Vogt A. A model of in situ immune complex glomerulonephritis in the rat employing cationized ferritin. Clin Nephrol 1980;14:211-216.

38 Vogt A. New aspects of pathogenesis of immune complex glomerulonephritis: formation of subepithelial deposits. Clin Nephrol 1984;21:15-20.

39 Vogt A, Rohrbach R, Shimizu F, et al. Interaction of cationic antigen with rat glomerular basement membrane: in situ immune complex formation. Kidney Int 1982;22:27-35. 